MIROWSKA Mariola,

Ph.D in Humanities in the Field of Pedagogy, Adjunct (Assistant Professor),

Head of Social Work and Public Health Department,

Jan Długosz University in Czestochowa, Republic of Poland e-mail: mmirowska@interia.pl

\title{
RISKS OF DISRUPTION OF EDUCATIONAL PROCESS BY A STUDENT: EVALUATION AT THE LEVEL OF A USER OF AN EDUCATIONAL SERVICE
}

\begin{abstract}
Introduction. The issue of the student support is increasingly typified as an urgent problem within the process of obtaining a higher education that meets the demands of the modern era and requires rather combined participation than the paternalistic approach. This raises the question how a higher educational institution should simultaneously support the student and form his personal autonomy. We have considered the accident analysis of student expulsion from HEI as a path for studying this issue, that can clarify the risks should be considered in the management of HEI in terms of building up of the student organizational support while obtaining a higher education.

The purpose is to determine a specific weight of the risks posed by student disruption of the educational process and opportunities for a higher education insti?ution to exert the directed influence over this process. Targets: 1) to define the percentage of those students who has discontinued studying in the HEI of Ukraine and to analyze the reasons stated by them; 2) to analyze the situations of students and identify potential opportunities for completing the process of obtaining a higher education.

Methods: evaluation of the HEI documents on the student expulsion from $\mathrm{HEI}$ or their transfer to extra?ural/part-time form of study during three years (20152017); interviewing students and teachers about their attitude to situations of student expulsion from HEI and further analysis of possible reasons; case management as a method for evaluation a student situation and support under the conditions of deficiency and social woes. The research was carried out in three HEI of Ukraine, namely, "University of Educational Management" (Kyiv); Sumy State A. S. Makarenko Pedagogical University (Sumy), Lesya Ukrainka Eastern European National University (Lutsk).

Results. The conducted analysis of the HEI documents revealed that a larger proportion of student expulsion is noted in cases of studying on their own expense. The expulsion situation commonly occurs after plenty student absence, curator warnings and statements
\end{abstract}

on the delay or absence of the student in classes, explanatory notes of the student himself on the intention to settle the situation, resume attendance of classes and work out missed sessions. Instead of this, the tipping point is the end-of-term exams, to which the student is not admitted because of the numerous "truancies". A typical scene was the situation of student expelling after 1-2 exam sessions in all HEI. The case management analysis carried out in all HEI revealed that the expulsion situation of can be prevented through taking into account the student social situation at the time of his admission to the HEI and the institutional control of the identified risk factors not by the virtue of punishment, but by the means of provision of information to the student on his oppor ?unities and support forms (internal-institutional and external as a general social environment), and method of case management can serve for this purpose.

Originality. The presentation of a case management method as a two-way process for student evaluation and support in the process of learning can prove particularly useful for forehanded changes in the organization management as an effective way to reach more learning service receivers.

Conclusion. The risk assessment of student disruption of the educational process and its consi?eration in the HEI management system may be significant for enhancing the student ability to complete the training in the HEI at the time of his admission into the HEI. Expansion of the system stimulating the student on the account of obtaining knowledge of the higher educational system, paying more attention to his needs and demands, creating space for self-development and self-organization are promising issues of the HEI development under the conditions of the information society establishment.

Keywords: case management; receiver-level evaluation; higher educational institution.

Одержано редакиією 07.06.2018 Прийнято до публікаиї̈ 14.06.2018

DOI 10.31651/2524-2660-2018-14-59-66

ORCID 0000-0002-8853-4538

НеСТУАЯ СвітАана Іванівна,

кандидат історичних наук, доцент кафедри управління персоналом та економіки праці, директор навчально-наукового інституту мідерства,

ВНЗ Укоопспілки "Полтавський університет економіки і торгівлі" e-mail: snestulya@gmail.com

УДК [316.46:336.2]:004.773.7

\section{БІЗНЕС-ФОРУМ ЯК ФОРМА РОЗВИТКУ МІДЕРСЬКОЇ КОМПЕТЕНТНОСТІ МАЙБУТНIХ БАКАМАВРІВ 3 МЕНЕДЖМЕНТУ}

У статті на основі аналізу наукових досліджень та власного практичного досвіду проведення бізнес-форумів визначено поняття бізнесфоруму як форми організаиії навчання майбутніх бакалаврів з менеджменту, спрямованої на фрормування їх лідерської компетентності. Запропоновано програму Міжнародного бізнесфоруму "Територія успіху. Бізнес та освіта: стратегічне партнерство", проведеного на базі вНЗ Укоопспілки "Полтавсъкий університет економіки і торгівлі. З'ясовано складові бізнесфорум як форми організаиї навчання майбутніх бакалаврів з менеджменту, спрямованої на формування їх лідерської компетентності: інорормаиійна, практико-орієнтована, інтерактивна, лідерсъко-управлінсъка, організаиійна та комп'ютерно-орієнтована.

Ключові слова: компетентність, лідер съка компетентність, менеджер, бакалавр, університет, лідер, бізнес-форум. 
Постановка проблеми. Сучасні світові тенденції соціально-економічного розвитку країн спонукають до подальшого творчого удосконалення освітніх систем та впровадження відповідних техномогій, спрямованих на забезпечення можАивості неперервного професійного навчання упродовж усього життя. 3 iншого боку, європейський вибір України та іï входження до європейського освітнього простору вимагають від вищої школи реформування, модернізації української системи освіти, впровадження в освітню практику нової управлінської парадигми, заснованої на мідерстві, особливо, в університетах, які здійснюють підготовку майбутніх бакалаврів з менеджменту, що у свою чергу обумовцює пошук нових освітніх парадигм та концепцій, принципів та підходів до організації освітнього процесу, а також засобів, методів та форм навчання студентів, які найбільш ефективно сприятимуть формуванню у них мідерської компетентності. Однією з таких форм $є$ бізнес-форум.

Незважаючи на те, що існуючі теоретичні та практичні підходи до проблеми формування $\Lambda$ дерської компетентності майбутніх бакалаврів 3 менеджменту (А. Балашов, О. Бойко, О. Видрашко, Т. Волосюк, В. Жигірь, О. Єрмоленко, В. Аугова, С. Козцовська, Г. Падурець, О. Долгопол, С. Тарасова, І. Чудаєва та ін.) внесли свій вагомий внесок у професійну підготовку студентів, недостатньо було розглянуто питання форм навчання, спрямованих на формування мідерської компетентності майбутніх бакалаврів 3 менеджменту в освітньому середовищі університету.

Мета статті: схарактеризувати суть бізнес-форуму як форми організації навчання майбутніх бакалаврів з менеджменту, спрямованої на формування їх мідерської компетентності.

Виклад основного матеріалу дослідження. Нове XXI століття вимагає i нової компетентності. Головний інструмент управління персоналом сьогодні мідерство, про це свідчить значна кількість досліджень зарубіжних авторів (Дж. Адаїр, М. Вебер, Р. Дафт, Дж. Канджемі, К. Ковальскі, Р. Мілмер, Р. Стогділ, Т. Хоммопетер та ін..) та продовження ними наукового пошуку. Необхідність дослідження накопиченого досвіду, адаптації існуючих підходів та опанування технологіями мідерства, форм навчання майбутніх менеджерів, за допомогою яких можливо розвивати їх мідерську компетентність, підсилює актуальність окресленої проблеми.

Сьогодні освіта стає каталізатором

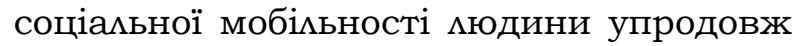
усього життя. Більш широкі можливості одержання освіти відкривають доступ до інтелектуальних, культурних, мідерських цінностей, розширюють кругозір, збільшують інтелектуальний потенціал більшої маси населення, розвивають їх мідерський потенціал. Технологічні передумови розвитку концепції неперервної освіти зводяться до розвитку технологій передачі інформації та технологій навчання (засобів, методів, форм).

Продовжуючи пошуки форм організації навчання майбутніх бакалаврів 3 менеджменту в освітньому середовищі ВНЗ Укоопспілки «Полтавський університет економіки і торгівлі", які б найкращим чином сприяли фрормуванню іx мідерської компетентності, ми зупинилися на бізнес-форумі.

На нашу думку, бізнес-форум $є$ однією 3 форм поглиблення i розширення професійної освіти, соціальної зрілості і професійної компетентності, виховання естетичного відношення до дійсності, збагачення культури ділового спілкування, розвитку мідерської компетентності студентів в освітньому середовищі університету та в процесі самоосвіти.

Аналіз наукових праць, присвячених формам навчання у сучасній дидактиці (С. Вітвицька, Г. Коджаспірова, Н. Кононец, С. Кульневич, Т. Аакоценіна, С. Максимюк, I. Малафіїк, Н. Мойсеюк, А. Кузьмінський, А. Хуторськой, В. Чайка), уможливлює зафіксувати двоїстість поняття "форма навчання" у контексті теорії навчання. Науковці наголошують, що варто розрізняти поняття "форми навчання" та "форми організації навчання". Форма навчання потрактовується як зовнішній вияв узгодженої діяльності викладача та студентів, яка здійснюється в певному порядку і режимі, у той час як форма організації навчання тлумачиться як обмежена часовими рамками конструкція окремої манки процесу навчання [2; 3 ; $5-$ 12].

Погоджуючись з Ю. Колеснік, нетрадиційні форми організації навчання - це можливість для студентів брати участь в ïx змісті. Найбільш ефективний засіб 
поєднання знань викладача (фахівцяпрофесіонала) з ціннісним змістом свідомості студента - це включення студента в спільну діяльність і по створенню заняття (практичного, семінарського заняття, мекції) чи певного заходу, і по його проведенню [4].

Обстоюючи позицію науковців, що форма організації навчання тлумачиться як обмежена часовими рамками конструкція окремої манки процесу навчання, ми розглядаємо бізнес-форум як форму організаиії навчання майбутніх бакалаврів з менеджменту, спрямовану на формування їх лідерської компетентності.

Бізнес-форум - це представницьке зібрання для широкого загалу представників бізнесу дмя обговорення дімових питань, яке, у свою чергу, може бути професійною навчальною платформою для майбутніх фахівців. Безумовно, бізнес-форму $\epsilon$ місцем для зустрічі бізнес-лідерів.

Аналіз сайтів, присвячених проведенню бізнес-форумів, та практика участі й проведення таких заходів на базі університету, засвідчили, що залучення студентів, майбутніх бакалаврів 3 менеджменту сприятиме:

- налагодженню співпраці університетів з представниками бізнесу регіону, України та зарубіжжя;

- ознайомленню 3 етичними нормами в сучасному менеджменті та бізнесі;

- озброєнню студентів знаннями, вміннями й навичками майбутньої професії в сучасному бізнесі;

- підсиленню ix практичної підготовки та збереження високого теоретичного рівня;

- розвитку в них творчих здібностей, ініціативності, самостійності, критичності, гнучкості, креативності мисмення;

- формуванню менеджера-мідера (формування мідерської компетентності студентів).

Відвідування бізнес-форумів навчать студентів: оперативно виявляти стратегії мислення співрозмовника; готувати виступи; готувати та проводити презентації; проводити успішні переговори; створювати презентації проекту, продукту, товару конкретно під особливості мисмення і сприйняття замовника; організовувати панельні дискусії, пленарні засідання, тематичні сесії, круглі столи, виставки, шоу-виставки; здійснювати електронну підтримку проведення форуму (створення Інтернет-ресурсів, реєстраційних форм) тощо.

Крім того, спілкування з провідними фахівцями-цідерами створює ту унікальну атмосферу мідерства, яка безпосередньо сприяє формуванню мідерів, здатних прогнозувати й адекватно реагувати на зміни, якими позначені як економічні, так і суспільні виклики нового часу, брати на себе відповідальність за їх впровадження, дікитися владою й демегувати вмадні повноваження, налаштованих на співробітництво.

Проведення бізнес-форуму на базі університету передбачає: вибір місця дия організації форуму; повне технічне оснащення; прийом і реєстрацію учасників; трансфер учасників; кампанію, що рекламує проведення форумів; запрошення представників ЗМI, їх акредитацію; підготовку друкованої продукції, прес-релізів, запрошень, сувенірів; розважальну програму в рамках організації форуму; організацію фуршету, прийому або брейк-кави; надання повного комплекту апаратури, необхідної для проведення форумів; надання аудіо- і відеозаписів заходів; організацію фотосесії; складання звіту про результати.

Проведення бізнес-форумів на базі університетів $\epsilon$ кроком до появи університетів нового покоління - університетів інноваиійного типу, які зможуть забезпечити підготовку фахівців і команд, здатних проектувати нові види діяльності та забезпечувати трансформацію вже існуючих корпорацій, галузей і територій відповідно до викликів часу. Як стверджують І. Артьомова, А. Волков, Д. Аіванов, попит на таких професіоналів, фахівців-лідерів інтенсивно зростає в усьому світі у зв'язку з посиленням глобальної конкуренції, появою нових технологій і геополітичною невизначеністю (фінансові та економічні кризи, мокальні військові конфлікти, проблеми соціальної сфери тощо). Такі університети, на думку дослідників, готуватимуть фахівців-лідерів, які будуть здатні: мислити за межами існуючих загальноприйнятих уявлень; вирішувати завдання, які досі не мали вирішення; діяти практично, беручи на себе відповідальність у ситуації невизначеності, обмеженості ресурсів і персонального ризику; 
доводити свою ефективність реальними досягненнями і результатами [1].

Нині, як можна спостерігати (аналіз офріційних веб-сайтів університетів), проведення бізнес-форумів $є$ поширеною практикою в освітній діяльності університетів. Одним із таких бізнес-форумів, який було організовано та проведено на базі ВНЗ Укоопспілки "Полтавський університет економіки і торгівлі", був Міжнародний бізнес-фрорум "Територія yсnіху. Бізнес та освіта: стратегічне партнерство", який став результатом тісної співпраці науково-педагогічного складу й адміністрації університету 3 представниками бізнесу (6 жовтня 2016 року). Цей захід приурочений до 150 років з дня заснування першого споживчого товариства в Україні та 45 річниці товарознавчо-комерційного факультету.

Організатори та учасники форуму спільними зусиляями розробили стратегічні напрями подальшої співпраці та партнерства, створили ефективні механізми підвищення конкурентоспроможності сучасних випускників, сформували концепції ефективного професійного і особистісного позиціонування випускника сучасного університету, формування їх мідерської компетентності в освітньому процесі університету, виробили новий формат та принципи роботи асоціації випускників.

Дия ефективної комунікації учасників була розроблена форма роботи панельна дискусія. Такий підхід сприяв ефективному діалогу представників бізнесу, влади, освіти, наукових шкіц й громадських організацій щодо проблем розвитку сучасної України, а також артикуляції вимог до підготовки фрахівців нової освітньої і професійної парадигми, в основі якої покладено концепцію формування мідерської компетентності студентів.

Усвідомлюючи масштабність репрезентативності випускників університету в усіх галузях народного господарства та їхній вагомий вклад у розвиток науки, бізнесу, освіти, університет ініціював підготовку до видання презентаційноіміджевого видання "Випускники ПУЕТ: історії успіху". Метою акумуляції багаторічного професійного досвіду поколінь випускників, фундаторів наукових i професійних шкіц, династій, успішних керівників-лідерів у різноманітних сферах економіки, суспіцьної і державної діяльності, стало його узагальнення та поширення серед широких суспільних кіл. Презентація книги відбулась в рамках бізнес-форуму за участю понад 200 випускників, авторського колективу, небайдужих та зацікавлених студентів та гостей міста [13; 14].

На етапі підготовки до форуму були залучені майбутні бакалаври 3 менеджменту, які допомагали викладачам готувати програму форуму, розробляти моготип, бланки запрошення, рекламний банер, стендову виставку "Випускники ПУЕТ: історії успіху", "ПУЕТ: сторінки історії" та фотовиставки "Історія в фотографіях"; розміщувати інформацію в мережі Інтернет, на сайтах університету та товарознавчо-комерційного факультету про проведення заходу й умови участі; розповсюджувати запрошення; виготовАяти подіум для проведення зустрічі 3 гостями форуму в холі університету; організувати зустріч, реєстрацію учасників та гостей Міжнародного бізнес-форуму; здійснювати кейтерингове обслуговування гостей та перерви на каву для учасників Міжнародного бізнес-форуму i бармен-шоу; організувати торгівлю сувенірною продукцією університету; проводити фотозйомки та фотосесіі; здійснювати підготовку та проведення брифінгу для ЗМI.

Програма Міжнародного бізнесфоруму "Територія успіху. Бізнес та освіта: стратегічне партнерство" подана у таблиці 1.

Як зазначає I. Артьомова, бізнесфорум $є$ програмою підприємницької освіти, яка забезпечує підвищення академічної мобільності студентів та викладачів, проведення активної політики трансферу наукових результатів у навчаАьний процес і професійне середовище, модернізацію освітньої діяльності університетів у цілому, а також сприяє розбудові партнерської мережі науки, освіти та бізнесу дия розв'язання спільних завдань ефективної економічної діяльності в Україні [1].

Загалом, ефективність формування мідерської компетентності майбутніх бакалаврів з менеджменту значною мірою залежить від вибору вдалих форм організації навчальної діяльності студентів та здатності науково-педагогічних кадрів університету правильно іх підготувати й провести, залучаючи до цього процесу й самих студентів. 
Програма Міжнародного бізнес-форуму

"Територія успіху. Бізнес та освіта: стратегічне партнерство»

\begin{tabular}{|c|c|c|}
\hline Назва заходу & $\begin{array}{l}\text { Місце та час } \\
\text { проведення }\end{array}$ & Відповідальні \\
\hline $\begin{array}{l}\text { Реєстрація гостей та учасників } \\
\text { Черговий реєстратор }\end{array}$ & $\begin{array}{l}9-00-10-00 \\
10-00-12-00 \\
\text { Хом } 1 \text { поверху }\end{array}$ & $\begin{array}{l}\text { Тягунова Н.М., Бабенко О.М. } \\
\text { Студентська рада ФТТМ }\end{array}$ \\
\hline $\begin{array}{l}\text { Зустріч випускників та колективу } \\
\text { факультету товарознавства, } \\
\text { торгів } і \text { та маркетингу “Зустріч } \\
\text { поколінь» }\end{array}$ & $\begin{array}{l}\text { 10-00 - 11-00 } \\
\text { ауд. 302, } \\
\text { Зама засідань }\end{array}$ & $\begin{array}{l}\text { Тягунова Н.М., } \\
\text { Завідувачі кафедр ФТТМ }\end{array}$ \\
\hline $\begin{array}{l}\text { Презентація книги "Випускники } \\
\text { ПУЕТ: історії успіху" }\end{array}$ & $\begin{array}{c}11-00-12-00 \\
\text { Читальна зала бібліотеки } \\
\end{array}$ & $\begin{array}{l}\text { Нестуля C.I., } \\
\text { Бабенко O.M. }\end{array}$ \\
\hline $\begin{array}{l}\text { Обрання керівництва Асоціації } \\
\text { випускників }\end{array}$ & $\begin{array}{c}12-00-12-30 \\
\text { Читальна зала бібліотеки }\end{array}$ & $\begin{array}{l}\text { Нестуля C.I., } \\
\text { Бабенко O.M. }\end{array}$ \\
\hline Кава-пауза, бармен-шоу & $\begin{array}{c}12-30-13-00 \\
\text { Хом читальної зали }\end{array}$ & $\begin{array}{l}\text { Котенко Н.Б., Бабенко О.М., } \\
\text { Єжов О. }\end{array}$ \\
\hline Автограф-сесія, фотосесія & Хом читальної зали & Бабенко O.М., фотографр \\
\hline $\begin{array}{l}\text { Міжнародний бізнес-форум } \\
\text { "Бізнес та освіта: стратегічне } \\
\text { партнерство»: }\end{array}$ & $\begin{array}{c}13-00-14-30 \\
\text { Читальна зала бібліотеки }\end{array}$ & $\begin{array}{l}\text { Гаркуша С.В., } \\
\text { Тягунова Н.М. }\end{array}$ \\
\hline $\begin{array}{l}\text { Територія успіху № } 1 \\
\text { «Що треба дмя успіху" }\end{array}$ & Хом університету & $\begin{array}{l}\text { Модератор - Делія О.В. } \\
\text { Спікери: }\end{array}$ \\
\hline $\begin{array}{l}\text { Територія успіху № } 2 \text { «Успіх в } \\
\text { підприємницькій діяльності» }\end{array}$ & Зала засідань & $\begin{array}{l}\text { Модератор - Юрко І.В. } \\
\text { Спікери: }\end{array}$ \\
\hline $\begin{array}{l}\text { Територія успіху №3 } \\
\text { «Успішні жінки в бізнесі» }\end{array}$ & ауд. 306 & $\begin{array}{l}\text { Модератор: Гвоздик Н.М. } \\
\text { Спікери: }\end{array}$ \\
\hline $\begin{array}{l}\text { Територія успіху №4 } \\
\text { «Кооперація в дії» }\end{array}$ & ауд.213 & $\begin{array}{l}\text { Модератор: } \text { Пантелеймоненко } \\
\text { А.О. } \\
\text { Спікери: }\end{array}$ \\
\hline $\begin{array}{l}\text { Територія успіху №5 } \\
\text { "Сучасний менеджер-лідер" }\end{array}$ & ауд. 224 & $\begin{array}{l}\text { Модератор: Костишина Т.А. } \\
\text { Спікери: }\end{array}$ \\
\hline $\begin{array}{l}\text { Територія успіху №6 } \\
\text { «Шкома мідерства» }\end{array}$ & ауд. 336 & $\begin{array}{l}\text { Модератор: Карманенко В.В. } \\
\text { Спікери: }\end{array}$ \\
\hline $\begin{array}{l}\text { Територія успіху №7 } \\
\text { "Формування мідерської компете- } \\
\text { нтності майбутніх бакалаврів } 3 \\
\text { менеджменту" }\end{array}$ & ауд. 131 & $\begin{array}{l}\text { Модератор: Нестуля С.I. } \\
\text { Спікери: }\end{array}$ \\
\hline Брифінг дмя ЗМІ & Кабінет ректора & Делія О.В. Тягунова Н.М. \\
\hline $\begin{array}{l}\text { Фото-виставка } \\
\text { (Історія в фотографіях) } \\
\text { "Как молоды мы были" }\end{array}$ & $\begin{array}{l}14-30-15-00 \\
\text { Хом } 2 \text { поверху }\end{array}$ & $\begin{array}{l}\text { Нестуля C.I., } \\
\text { Бабенко O.M. }\end{array}$ \\
\hline $\begin{array}{l}\text { Урочистості з нагоди 45-річчя } \\
\text { товарознавчого факуиьтету }\end{array}$ & $\begin{array}{l}15-00-17-00 \\
\text { Актова зала } \\
\text { університету }\end{array}$ & $\begin{array}{l}\text { Тягунова Н.М., Нартова I.В., } \\
\text { Тютюнник Н.В., } \\
\text { студентська рада ФТТм }\end{array}$ \\
\hline Вечір-зустріч "В колі друзів» & $\begin{array}{c}18-00-21-00 \\
\text { Ресторан "Міміно" }\end{array}$ & $\begin{array}{l}\text { Нестуля С.І., Тягунова Н.М. } \\
\text { Бабенко О.М. }\end{array}$ \\
\hline
\end{tabular}

Концепція проведення будь-якого бізнес-форуму розробляється відповідно орієнтованої схеми (рис. 1).

Розглядаючи бізнес-форум як форму організації навчання майбутніх бакалаврів з менеджменту, спрямовану на формування їх цідерської компетентності, можемо виділити такі його складові: інформаиійна складова - вивчення теоретичних основ широкого спектру дисциплін професійно-орієнтованого циклу (студенти отримують актуальну практико-орієнтовано інформацію, відвідуючи "території успіху", панельні дискусії, круглі столи тощо); 
практико-орієнтована складова активізація навчально-пізнавальної діяАьності студентів щодо виконання завдань 3 навчальних практик, курсових робіт, проектів (використання отриманої інформації у практичних цілях);

інтерактивна складова - унікальна можливість для майбутніх бакалаврів 3 менеджменту налагодження комунікацій з представниками бізнесу, керівникамимідерами (знайомства, спілкування, бесіди, розповіді, питання-відповіді) тощо;

лідерсъко-управлінсъка складова студенти навчаються управцяти вмасним навчанням, життям, досягати успіху у майбутній професії, отримують знання про мідерів, розвивають мідерські якості, навчаються мідерської поведінки (формування мідерської компетентності);

організаційна складова - студенти навчаються організовувати та проводити подібні заходи (панельні дискусії, пленарні засідання, тематичні сесії, круглі столи, виставки, шоу-виставки тощо);

комп'ютерно-орієнтована складова студенти навчаються здійснювати електронну підтримку проведення форуму (створення Інтернет-ресурсів, веб-сайтів, наповнення веб-сайтів контентом, розробка реєстраційних форм, електронних інформаційних матеріалів, банерів, букцетів тощо).

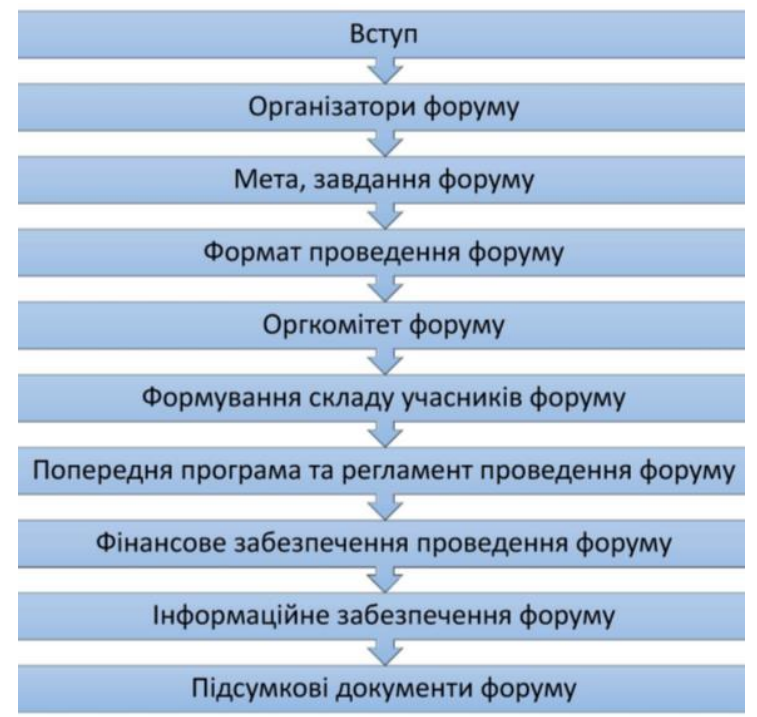

Рис. 1. Концепція бізнес-форуму

Слід погодитися з Ю. Колеснік, що такі нетрадиційні форми організації навчання демонструють, у першу чергу, результати взаємодії в навчанні, яку слід розуміти не як якість засвоєних знань, а ті зміни, які відбуваються в особистості студента, в його розвитку і зростанні. До них відносяться такі зміни: студент починає сприймати себе інакше; студент більш повно приймає себе і свої відчуття; стає впевненішим в собі і автономним; ставить перед собою реальні цілі, поводиться зріліше; стає більш схожим на мюдину, якою хотів би бути; починає приймати і розуміти інших Аюдей [4].

Висновки $i$ перспективи подамьших досліджень. Наприкінці відзначимо, що проведення бізнес-форумів як нетрадиційної форми навчання студентів в університеті уможливлює не $\Lambda и-$ ше підняти їх інтерес до майбутньої професійної діяльності, до гАибокого вивчення професійно-орієнтованих дисциплін, але й розвивати їх творчу самостійність, критичність, креативність, навчати роботі 3 різними джерелами знань, отримувати знання у процесі спілкування, у прагненні до успіху. Такі форми організації навчання різноманітять традиційність освітнього процесу в університеті, пожвавцюють думку, активізують організаційну та управлінську діяльність, відтак, сприяють формуванню мідерської компетентності майбутніх бакалаврів 3 менеджменту. 3 іншого боку, відвідування бізнес-форумів у подальшій професійній діяльності сучасних менеджерів створює умови постійного самовдосконалення, підвищення професійної майстерності, розвитку мідерської компетентності і є запорукою можливості неперервного професійного навчання упродовж усього життя.

Перспективи подальших досліджень вбачаємо у розширенні переліку нетрадиційних форм організації навчання майбутніх бакалаврів 3 менеджменту, спрямованих на формування їх мідерської компетентності.

\section{Список бібліографічних посимань}

1. Артьомова I.В. (2015). Інноваційна діяльність університетів України: аналітичний огмяд. Інформаиійний бюлетень наукового проекту "Інноваційний університет - інструмент інтеграцї̈ в європейсъкий освітній $і$ науковий простір». Вип. 1. Ужгород. 158 с.

2. Вітвицька С.С. (2006). Основи педагогіки вищої школи: підручник за модульно-рейтинговою системою навчання для студентів магістратури. Київ: Центр навчальної мітератури. 384 с.

3. Коджаспирова Г.М. (2007). Педагогика в схемах, таблицах и опорных конспектах. 2-е изд. М.: Айрис Пресс. 256 с.

4. Колеснік Ю.Ю. (2018). Використання нетрадиційних форм навчання в процесі екологічного виховання молодших школярів. Young Scientist. № 1(53). C. $317-322$. 
5. Кононец Н.В. (2016). Дидактичні основи ресурсно-орієнтованого навчання дисципмін комп'ютерного циклу студентів аграрних комеджів: дис. ... д-ра пед. наук. Полтава. 473 с.

6. Кузьмінський A.I. (2005). Педагогіка вищої школи: навч. посіб. Київ: Знання. 486 с.

7. Кумьневич С.В., Макоценина Т.П. (2006). Не совсем обычный урок : практическое пособие для учителей и кмассных руководителей, студентов средних и высших педагогических заведений, слушателей ИПК. Воронеж: Аакоценин С. С. $175 \mathrm{c}$.

8. Максимюк С.П. (2005). Педагогіка: навч. посіб. Київ: Кондор. 667 с.

9. Малафіїк I.B. (2009). Дидактика: навч. посіб. Київ: Кондор. 406 с.

10. Мойсеюк Н.Є. (2007). Педагогіка : навч. посібник . 5-те вид., доповнене і перероблене. Київ: Мойсеюк В.Ю. 656 с.

11. Хуторской А.В. (2001). Современная дидактика: учебн. дия вузов. СПб.: Питер. 544 с.

12. Чайка В.М. (2011). Основи дидактики: навч. посіб. Київ: Академвидав. 238 с.

13. Територія успіху. Бізнес та освіта: стратегічне партнерство (2018). Puet.edu.ua. URL: http://puet.edu.ua/uk/teritoriya-uspihu-biznes-taosvita-strategichne-partnerstvo.

14. Міжнародний бізнес-форум у ПУЕТі: стратегічні дискусії, історії успіху, неоціненний досвід (2018). Coop.com.ua. http://www.coop.com.ua/ru/news/393.

\section{References}

1. Artyomova, I.V. (2015). Innovative activity of Ukrainian universities: analytical review. Newsletter of the scientific project "Innovation University - an instrument of integration into the European educational and scientific space". Whip 1. Uzhgorod. $158 \mathrm{p}$.

2. Vitvitskaya, S. S. (2006). Fundamentals of higher education pedagogy: a textbook for modular-rating system of study for students of the magistracy. Kyiv: Center for Educational Literature. 384 p.

3. Kodjaspirova, G.M. (2007). Pedagogy in charts, tables and reference notes. 2nd ed. Moscow: Iris Press. 256 p.

4. Kolesnik, Yu.Yu. (2018). Use of non-traditional forms of education in the process of environmental education of junior pupils. Young scientist. 1(53). 317-322.

5. Kononets, N.V. (2016). Didactic bases of resourceoriented training of disciplines of the computer cycle of students of agrarian colleges. (Doctor Sciences in Pedagogy). Poltava. 473 p.

6. Kuzminsky, A.I. (2005). Pedagogy of higher education: teaching. manual K. Knowledge. 486 p.

7. Kulnevvich, S.V., Lakozhenyna, T. P. (2006). Not quite an ordinary lesson: a practical manual for teachers and class leaders, students of secondary and higher pedagogical institutions, students of the IPC. Voronezh: Lakozhenin S. 175 p.

8. Maximyuk, S.P. (2005). Pedagogy: Teacher manual. Kyiv: Condor. 667 p.

9. Malafiik, I.V. (2009). Didactics: Teaching manual. Kyiv: Condor. 406 p.

10. Moiseyuk, N. E. (2007). Pedagogy: Teacher manual 5 th form, supplemented and redone. Kyiv: Moiseyuk V.Yu. $656 \mathrm{p}$.

11. Khutorskaya, A.V. (2001). Modern didactics: study. for high schools. SPb : Peter $544 \mathrm{p}$

12. Chayka, V.M. (2011). Basics of didactics: teach. manual. Kyiv: Academic Edition. 238 p.

13. The territory of success. Business and Education: Strategic Partnership (2018). Puet.edu.ua. Retrieved 18 September 2018, from http:// puet.edu.ua/uk/teritoriya-uspihu-biznes-taosvita-strategichne-partnerstvo.

14. International business forum in PUTE: strategic discussions, success stories, invaluable experience (2016). Coop.com.ua. Retrieved 18 September 2018, from http://www.coop.com.ua/ru/news/393.

\section{NESTULYA Svitlana,}

Ph.D in History Sciences, Associate Professor of Personnel Management and Labor Economics Department, Director of the Educational and Scientific Institute of Leadership,

University of Ukoopspilks "Poltava University of Economics and Trade".

\section{e-mail: snestulya@gmail.com}

\section{BUSINESS FORUM AS THE FORM OF DEVELOPMENT OF LEADERSHIP COMPETENCE OF FUTURE BACHELORS IN MANAGEMENT}

Abstract. Introduction. Modern world trends in socio-economic development of countries encourage further creative improvement of educational systems and the introduction of appropriate technologies aimed at ensuring the possibility of lifelong lifelong vocational training. On the other hand, Ukraine's European choice and its entry into the European educational space require higher education reform, modernization of the Ukrainian educational system, the introduction of a new management leadership paradigm in educational practice, especially in universities that train future bachelors in management, which in turn leads to the search for new educational paradigms and concepts, principles and approaches to the organization of the educational process, as well as the means, methods and forms of teaching of students who are most ilsh effectively contribute to the formation of their leadership competencies. One such form is a business forum.

The purpose of the article: to characterize the essence of the business forum as a form of organization of training future bachelors in management, aimed at forming their leadership competencies.

Methods of research - analysis, synthesis, generalization, pedagogical observation, pedagogical survey.

Results. The business forum is one of the forms of deepening and expanding vocational education, social maturity and professional competence, forming the leadership competency of students in the educational envi- ronment of the university and in the process of selfeducation.The business forum is a form of training for future bachelors in management aimed at building their leadership competencies.

The business forum is a representative meeting for the general public of business representatives to discuss business issues, which in turn can be a professional training platform for future professionals. Of course, the business form is a place to meet business leaders.

An analysis of sites devoted to business forums, and the practice of participating and conducting such events on the basis of the university, have shown that attracting students, future bachelors of management will contribute: to establish cooperation between universities and representatives of business in the region, Ukraine and abroad; acquaintance with ethical standards in modern management and business; arming students with the knowledge, skills and abilities of the future profession in modern business; strengthening their practical training and maintaining a high theoretical level; the development of their creative abilities, initiative, autonomy, criticality, flexibility, creativity thinking; formation of a leadermanager (formation of leadership competency of students).

Visiting business forums will teach students: to quickly identify the strategies of thinking the interlocutor; prepare speeches; to prepare and hold presentations; 
conduct successful negotiations; create presentations of a project, a product, a product specifically for the specifics of thinking and perception of the customer; to organize panel discussions, plenary sessions, thematic sessions, round tables, exhibitions, show-shows; to provide electronic support for the forum (creation of Internet resources, registration forms), etc. In addition, communication with leading leadership specialists creates the unique atmosphere of leadership that directly contributes to the formation of leaders capable of predicting and responding adequately to changes that indicate both the economic and social challenges of the new time, take responsibility for their implementation, share authorities and delegate power-oriented, co-opted.

Originality. University-based business forums are a step towards the emergence of new generation universities - innovative universities that can provide training for professionals and teams capable of designing new activities and ensuring the transformation of existing corporations, industries and territories in line with the challenges of the time. Today, as you can see (analysis of official websites of universities), business forums are a common practice in the educational activities of universities. One of these business forums, which was organized and conducted on the basis of the University of Ukoopspilks "Poltava University of Economics and Trade", was the International Business Forum "The Territory of Success. Business and Education: Strategic Partnership ", which was the result of close cooperation of the scientific and pedagogical staff and administration of the University with business representatives (October 6, 2016).

Conclusion. Considering the business forum as a form of organization of training for future bachelors in management aimed at forming their leadership competence, the author proposes to focus on the following components:

Information component - studying the theoretical foundations of a wide range of disciplines in a professionally-oriented cycle (students receive relevant practical information, visiting "territories of success", panel discussions, round tables, etc.);

Practical-oriented component - activation of educational and cognitive activity of students on the implementation of tasks from educational practices, term papers, projects (use of the information for practical purposes);

Interactive component - a unique opportunity for future bachelors in management of communication with business representatives, leaders-leaders (dating, communication, conversation, storytelling, question-answer), etc.;

Leadership-management component - students learn to manage their own learning, life, achieve success in the future profession, gain knowledge about leaders, develop leadership skills, learn leadership skills (forming leadership competencies);

Organizational component - students learn to organize and conduct similar events (panel discussions, plenary sessions, thematic sessions, round tables, exhibitions, show-shows, etc.);

Computer-oriented component - students learn to provide electronic support for the forum (creation of Internet resources, websites, content filling websites, development of registration forms, electronic information materials, banners, booklets, etc.).

The author proposes the Program of the International Business Forum "The Territory of Success. Business and Education: Strategic Partnership ". Visit of business forums in the further professional activity of modern managers creates conditions for constant self-improvement, professional development, development of leadership competence and a guarantee of the possibility of continuous professional training throughout their lives.

Keywords: competence, leadership competence, manager, bachelor, university, leader, business forum.

Одержано редакиією 23.09.2018 Прийнято до публікаиї̈ 01.10.2018

DOI 10.31651/2524-2660-2018-14-66-72

ORCID 0000-0001-6814-4666

ПАІСКО Вамерій Іванович,

доктор педагогічних наук, професор,

Національний університет "Чернігівський комегіум» імені Т. Г. Шевченка e-mail: pliskoej@ukr.net

ORCID 0000-0002-0170-2616

\section{БОНДАРЕНКО ВаАенТин Володимирович,}

кандидат педагогічних наук, доцент,

Національна академія внутрішніх справ e-mail: guryavvb@ukr.net

УДК 377.36.091.3:351.74

\section{ВПАИВ СИСТЕМИ ПОЕТАПНОЇ ПІДГОТОВКИ НА РОЗВИТОК КОГНІТИВНОГО КРИТЕРІЮ ПРОФЕСІЙНОЇ ГОТОВНОСТІ МАЙБУТНІХ ПРАЦІВНИКІВ ПАТРУМЬНОї ПОАІЩІї}

у статті висвітлено експериментальну перевірку впливу запропонованих новаиій системи поетапної підготовки на динаміку показників когнітивного критерію професійної готовності майбутніх праиівників патрульної поліuіï. У експерименті брали участь слухачі курсу первинної професійної підготовки поліиейсъких Наиіональної академії внутрішніх справ ( $n=61)$. Слухачі KГ (n=30) навчалися за чинною професійною програмою, ЕГ (n=31) - відповідно до розробленої системи поетапної підготовки, ио реалізовувалася завдяки иілеспрямованому ро- звиткові професійно важливих якостей; застосуванню ситуаиійних завдань під час опанування тактичної $i$ вогневої підготовок; використанню варіативних ситуаиійних задач під час проходження рольових ігор (сиенаріїв).

математичне опраиювання результатів тестування слухачів ЕГ на формувальному етапі педагогічного експерименту засвідчило достовірне підвищення більшості досліджуваних показників (p<0,05). Такі результати дають підстави стверджувати про позитивний вплив запропонованих новацій на розвиток показників 